\title{
INTERNATIONAL STANDARDIZATION IN THE DESIGN OF "SHORE TO SHIP” - POWER SUPPLY SYSTEMS OF SHIPS IN PORT
}

\author{
Dariusz TARNAPOWICZ \\ Akademia Morska w Szczecinie \\ Sergiej GERMAN-GALKIN \\ University ITMO, Sankt Petersburg
}

\begin{abstract}
:
The decisive source of air pollution emissions in ports is the berthed ships. This is primarily caused by the work of ship's autonomous generator sets. One way of reducing the air pollution emissions in ports is the supply of ships from electricity inland system. The main problem connected with the power connection of ships to the inland network is caused by different values of levels and frequencies of voltages in these networks (in various countries) in relation to different values of levels and frequencies of voltages present in the ship's network. It is also important that the source power can range from a few hundred kW up to several MW. In order to realize a universal "Shore to Ship” system that allows the connection of ships to the electricity inland network, the international standardization is necessary. This article presents the current recommendations, standards and regulations for the design of „Shore to Ship" systems.
\end{abstract}

Key words: "Shore To Ship" system, High Voltage Shore Connection, Low Voltage Shore Connection

\section{INTRODUCTION}

In recent years, the problem of air pollution and (consequently) the impact of air quality on human health and natural environment became important. Children and older people constitute a group of people particularly exposed to air pollution.

In port cities, the sources of air pollution include, for example, ocean going vessels, public transport, trucks in port, locomotives and heating. Studies conducted in many ports show that a decisive source of air pollutions are sea vessels, which moor in ports [1]. Fig. 1 shows examples of researches of emissions sources of sulphur dioxide $\left(\mathrm{SO}_{2}\right)$ and nitrogen oxides $\left(\mathrm{NO}_{\mathrm{X}}\right)$ from various sources made in the port of Lubeck [2].

Mainly for operational purposes, ships at berth in the port require a source of electrical power supply. Therefore, sea vessels use electricity produced by autonomous power generating sets Diesel-Generator (D-G). Each D-G power generating set, depending on the power plant, consume approx. a few tons of fuel per day. Of course, the amount of consumed fuel can significantly grow, when vessels use their own handling equipment. D-G generating sets work 24 hours a day and emit toxic compounds into the atmosphere. It should be emphasized that marine generating sets are a source of noise and vibrations [1], which also has a negative impact on the health of people working in the port and local residents.

A natural way to reduce the exhaust emissions in ports is a deactivation of D-G marine power generator sets and replacing them with the supply from the electricity inland network.

Seemingly simple operation is complicated because of the lack of uniform electricity systems in the world and electricity networks on ships. The specificity of ship's network implies specific requirements $[3,4]$.

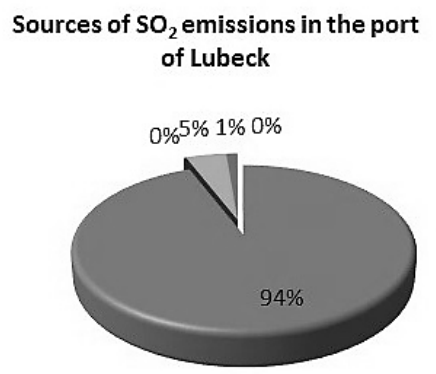

Sources of $\mathrm{NO}_{\mathrm{x}}$ emissions in the port of Lubeck

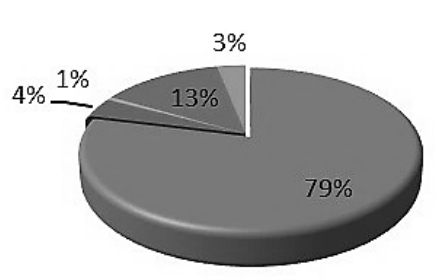

주으. going vessels

圆 heating

ब public transport 
Fig. 2 presents the differences in the frequency of voltage in the power grids in the world. The frequency in Europe is $50 \mathrm{~Hz}$, in both Americans (mostly) $60 \mathrm{~Hz}$. Japan in its western part uses $60 \mathrm{~Hz}$, and in the eastern part $-50 \mathrm{~Hz}$.

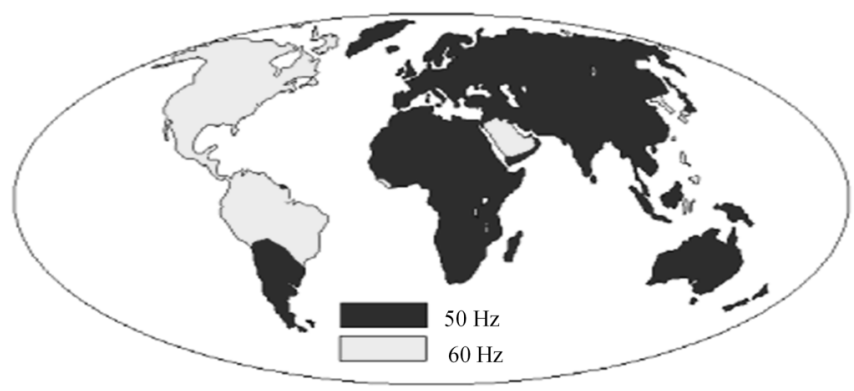

Fig. 2 Frequencies of power supply voltages of the world

Frequency of marine networks mostly depends on the type of ship, as well as regions, in which it sailing (this is mainly referred to ferries and cruise ships). Figure 3 shows differences in the frequency of marine networks, depending on the type of ship.

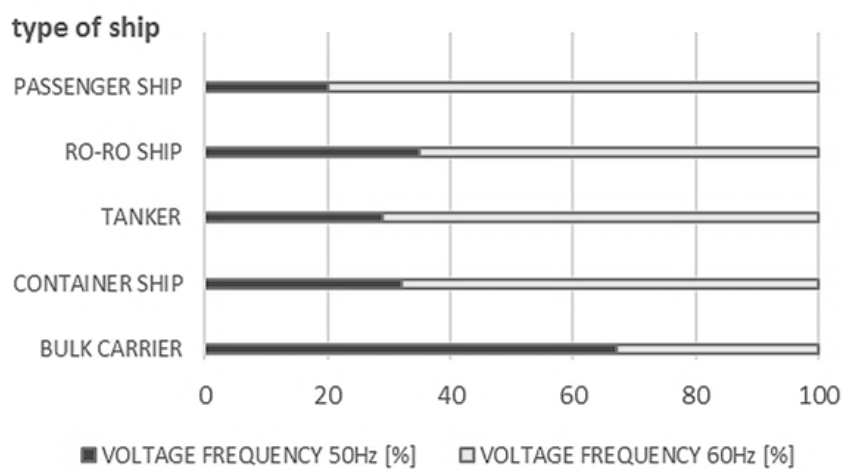

\section{Fig. 3 Frequencies of voltages of ships power network}

The electricity marine networks are characterized by various voltage levels depending on the type of ship. Vessels with small power plants (e.g. bulk carriers) usually have low voltage $(<1 \mathrm{kV}) 380 \mathrm{~V}, 400 \mathrm{~V}, 440 \mathrm{~V}, 450 \mathrm{~V}$ or $660 \mathrm{~V}$. Vessels with larger capacities are equipped with electricity networks of medium voltage $3.3 \mathrm{k} \mathrm{V}, 6.6 \mathrm{k} \mathrm{V}$ or $11 \mathrm{kV}$. Adjustment of the voltage level is relatively simple. It is made with the use of transformers. Frequency conversion requires the use of frequency converters, which greatly com- plicate the construction of the STS system and increase its costs.

Ensuring the full compliance between the marine electrical network and inland electricity network has become the most important task.

\section{ORIGIN OF THE FIRST REGULATIONS FOR THE STANDARDI- ZATION OF STS SYSTEM}

The first systems to connect vessels to the inland electricity network were built for the US Navy in the early $90 \mathrm{~s}$ [1]. The power supply voltage was $480 \mathrm{~V} / 60 \mathrm{~Hz}$. In order to ensure the transfer of large power energies, a considerable amount of connecting cables were required. The operation of connecting the vessel took over 2 hours. Such solutions for commercial vessels could not be applied. Stay at the port is often short.

For commercial vessels, systems for connection with the land (created in the 80s) did not ensure the versatility (especially the lack of frequency conversion) and global standards for the connecting elements.

The first international regulations, which began to emphasize the importance of the power connection to the mainland, have been included in the Directive of the European Union in 1999. The Directive [5] discharges vessels, with the exception of all engines and vessels using electricity supplied from the mainland while mooring in ports, from the requirement to use marine fuel with a sulfur content not exceeding $0.1 \%$ per unit of mass.

On 12 May 2006, the European Union issued a Commission's recommendation 2006/339/EC on the promotion of shore-side electricity for use by ships at berth in EU ports [6]. Based on the EU Treaty and the earlier arrangement, e.g. connected with the use of total or partial tax exemptions or reductions in tax rates for electricity [7] supplied from shore to ship, the European Union recommended for the Members the construction and development of systems for gathering shore-side electricity by vessels at berth in EU ports. Member States should take into account technical advices presented in the Annex to the recommendations. The annex has been divided into 4 main chapters:

- Technical requirements - typical configuration,

- Benefits - emissions reductions,

- Costs - capital expenditure and operating costs,

- Comparison of benefits and costs.

The chapter related to the technical requirements determined the main elements of STS system. Fig. 4 shows a configuration of STS system based on the annex to the EU recommendations [6].

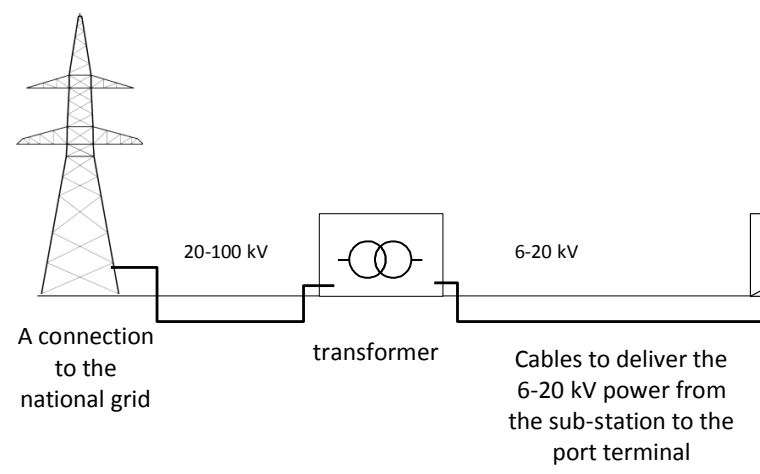
port terminal

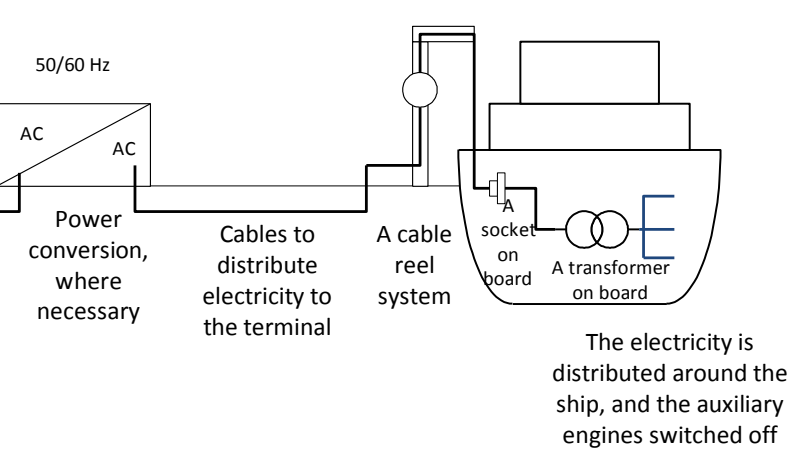


The recommendations set out in the Regulations 2006/339/EC did not include any details about STS systems, but only general guidelines. Provision of the full standardization between the electrical marine network and onshore power supply network has become a priority.

\section{HIGH VOLTAGE SHORE CONNECTION}

Global standardization contributes to the unification of STS equipment by avoiding differences in technical characteristics of the systems in terms of operational security, system's safety and normalization of connecting elements.

A key organization that dealt with the standardization of regulations was the IEC (International Electrotechnical Commission). IEC is an international (global) organization. The mission of this organization is to develop the international normalization through the cooperation of its members in all matters related to the electro-technical standardization. The scope of IEC covers the entire area of electricity.

Works on the new standard were conducted by the IEC Technical Committee 18 Electrical Installations of Ships and of Mobile and Fixed Offshore Units, IEC Subcommittee $23 \mathrm{H}$ Industrial Plugs and Socket-Outlets, IEC Technical Committee 23 Electrical Accessories, ISO (International Organization for Standardization) Technical Committee 8 Ships and Marine Technology, and IEEE P171 Electrical Shore-toShip Connections Working Group. The first meeting of representatives from the IEC's working group was held in September 2006 in the United States. In December 2006, the IEC started to cooperate with a group of representatives from ISO, and in December 2008 - the IEC established the cooperation with IEEE's representatives. In the period from December 2008 to October 2011, the IEC/ISO/IEEE group met 8 times.

The first International Standard for STS system, marked as IEC/ISO/IEEE 80005-1 Utility Connections in Port-Part 1: High Voltage Shore Connection (HVSC) Systems - General Requirements [8], was presented in July 2012. This standard replaces the previously issued standard (IEC/PAS 60092 -510:2009 Electrical installations in ships - Special features - High Voltage Shore Connection Systems - HVSC Systems)

The main assumption of the standard is that the transmission of electricity from shore to ship berthed in the port must be performed at a medium voltage, which is strictly standardized and commonly called a high voltage.

The standard consists of 12 chapters and 6 annexes, 5 of which set out additional requirements in terms of different types of floating vessels. One information annex concerns the details about the connecting cable between the mainland and the vessel.

The standard determines major issues of the standard related to the electrical shore to ship connection:

- allocation for the power of marine systems from 1 MVA to 20 MVA,

- parameters of supply voltages $6.6 \mathrm{kV}$ or $11 \mathrm{kV}, 50$ or $60 \mathrm{~Hz}$ (IEC60038 allows for ranges: 6-6.6 and 10-11 $\mathrm{kV})$,

- quality of supply voltages existing in marine systems,

- galvanic separation between the electrical land and marine network,

- standard plugs and sockets available in HV systems,

- requirements for marine devices and installations,

- requirements for land devices and installations,

- requirements for the systems of the ship during the connection to the land installation.
Fig. 5 shows a diagram containing the main elements of STS-HVSC consistent with IEC/ISO/IEEE 80005-1 standard [8].

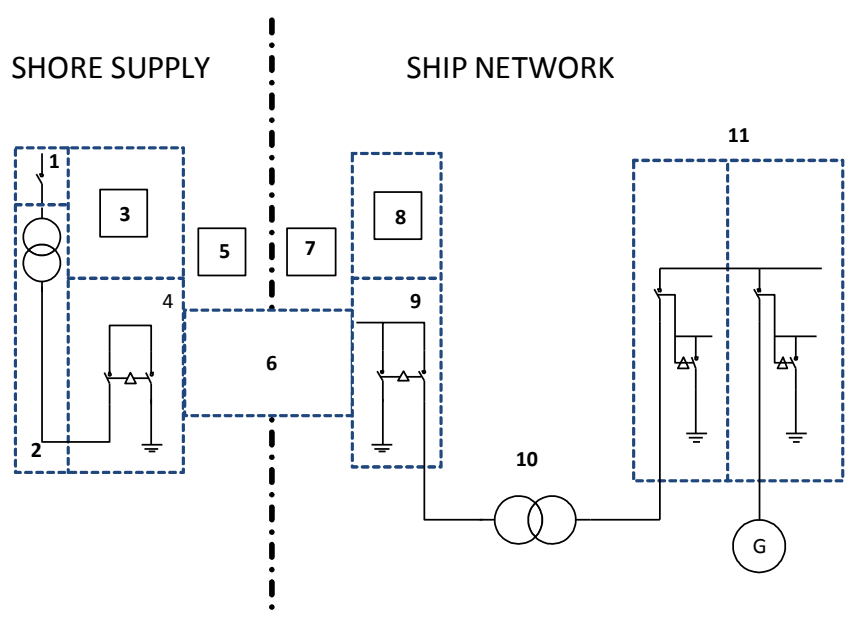

Fig. 5 Blok diagram of a typical described STS-HVSC system arrangement of IEC/ISO/IEEE 80005-1

1 - HV-shore supply system, 2 - shore side transformer, 3 - shore side protection relaying, 4 - shore side circuit breaker and earth switch, 5 - control, 6 - shore to ship connection and interface equipment, 7 - control, 8 - ship protection relaying, 9 - shore connection switchboard, 10 - on board transformer, 11 - on board receiving switchboard

Transition from power from autonomous marine power generators to mainland power and vice versa is uninterrupted by synchronization [9].

As it was already mentioned, STS-HVSC system presented in the IEC/ISO/IEEE 80005-1 standard includes requirements for vessels, which power requirement ranges from 1 MVA to 20 MVA. There is a group of vessels, which are not covered by this standard. Fig. 6 presents the demand for electric power during the stop of a vessel in the port, taking into account peak loads. Statistical analysis was performed on the basis of data from records of vessels for various classification companies. The summary shows that there is a group of vessels, which do not require a large power demand during the stop in port ( $<1 \mathrm{MVA})$.

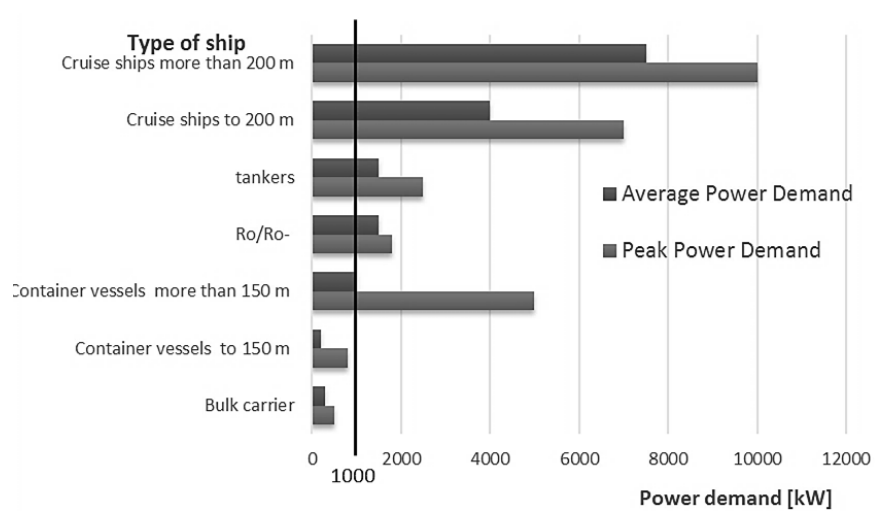

Fig. 6 Power demand of different ships in port

\section{LOW VOLTAGE SHORE CONNECTION}

In the case of demand for electricity at low power, there is no need for power transmission at high voltages. IEC/ ISO/IEEE working groups worked on standardization, which applied to vessels not covered by the IEC/ISO/IEEE 80005-1 standard - i.e. vessels with a power demand in the port 
below 1 MVA (Fig. 6). Just like the standard concerning STSHVSC standard, the same groups prepared a standard for STS-LVSC (STS - Low Voltage Shore Connection) systems. In August 2014, a preliminary version of the EC/ISO/IEEE 80005-3 [10] standard: 2014 Utility connections in port Part 3: Low Voltage Shore Connection (LVSC) Systems General requirements was adopted. This standard describes low-voltage shore connection (LVSC) at transmission currents, which do not exceed 250 A (maximum 125 A per cable) and a voltage not exceeding $300 \mathrm{~V}$ in relation to earth. Vessels, which exceed the above-mentioned values, must use the STS-HVSC system.

IEC/ISO/IEEE 80005-3 standard specifies the basic elements of the system that are both on the vessel and on land.

This standard is applicable to the design, installation and testing of LVSC systems and following addresses:

- LV shore distribution systems,

- shore-to-ship connection and interface equipment,

- transformers/reactors,

- semiconductor/rotating convertors,

- ship distribution systems,

- control, monitoring, interlocking,

- power management systems.

The standard lists the requirements concerning the security of LVSC system - control, monitoring and safety systems. This standard emphasizes that it cannot be used during the docking of vessels in shipyards. Fig. 7 shows a diagram containing the main elements of STS-LVSC system consistent with the IEC/ISO/IEEE 80005-3 standard [10].

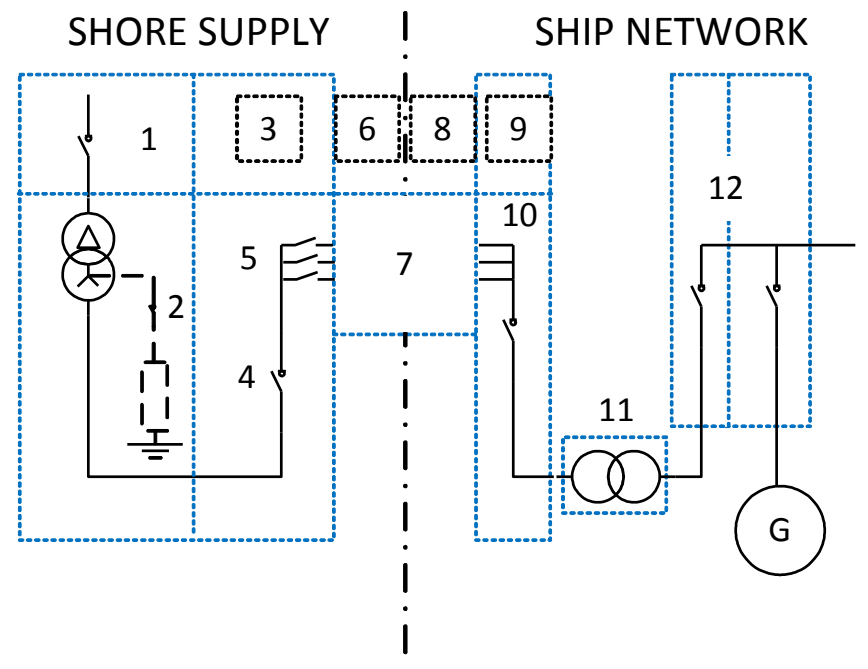

Fig. 7 Blok diagram of a typical described STS-LVSC system arrangement of IEC/ISO/IEEE 80005-3

1 - shore supply system, 2 - shore-side transformer and neutral grounding resistor or/and it system, 3 - shore-side protection relaying, 4 - shore-side circuit-breaker, 5 - shore-side feeders circuit breakers, 6 - control shore, 7 - shore-to-ship connection and interface equipment, 8 - control ship, 9 - ship protection relaying, 10 - on-board shore connection switchboard, 11 - on-board transformer (where applicable), 12 - on-board receiving switchboard

The guidelines contained in the standard should be taken into account the engineering companies, ports and shipping companies in the scope of design, installation and testing of LVSC systems.
The first port that performed the installation of STSLVSC system according to the IEC/ISO/IEEE 80005-3 standard is the port of Bergen in Norway. Construction of STS system was finished in 2016. STS-LVSC system guarantees the power supply at a voltage of 440 or $690 \mathrm{~V}$ and the frequency of 50 or $60 \mathrm{~Hz}$ [11]. The power cord on the wharf (with the option of using 1 or 2 cables) has a length of 30 $\mathrm{m}$. The connecting elements (sockets and plugs) were design in accordance with the standard.

\section{CONCLUSIONS}

Reduction of air pollution emissions by seagoing ships, and thus the meeting of high environmental requirements, is connected with searching for new technical solutions. STS system is the most effective solution.

The use of STS systems for vessels berthed in the port must be preceded by global standardization of regulations in order to ensure the universal character of the projected system and the use of these systems by different types of ships.

The common work (in recent years) of IEC, IEEE and ISO experts resulted in the development of standards that enable the building of STS systems. HVSC standard for vessels with the power of a power plant above $1 \mathrm{MVA}$ (IEC/ISO/ IEEE 80005-1) and LVSC standard for ships under 1MVA (IEC/ISO/IEEE 80005-3) enabled the implementation of new STS systems, which are consistent with the global standards.

Standardization increases the compatibility between electrical installations on land and on the ship. An important aspect determined in both standards is a widely understood security, which should be considered when designing the STS system.

This research outcome has been achieved under the research project: Nowoczesne technologie w systemach

"Shore to Ship" No 2/S/IEiAO/16 financed from a subsidy of the Ministry of Science and Higher Education for statutory activities

\section{REFERENCES:}

[1] D. Tarnapowicz and T. Borkowski, Shore to Ship System: Alternative Power Supply of Ships in Ports. Szczecin: Scientific Publishing House of the Maritime University, 2014.

[2] German Meteorological Service/Hanseatic City of Lübeck, Environmental Protection Department. (2017, Feb. 01). Fresh Air for Port Cities. Research project explores ways to reduce pollutant emissions from ships in Baltic Sea ports [Online]. Available: http:// www.umweltbundesamt.de/sites/default/files/ medien/publikation/short/k3004.pdf

[3] G. Nicewicz, M. Sosiński and D. Tarnapowicz, "Identification of power factor in marine electrical grid", in 14th GeoConference Energy and Clean Technologies, vol. 2, Albena, Republic of Bulgaria, 2014, pp. 391-398.

[4] Z. Matuszak and G. Nicewicz, "Analysis of Marine Electric Power Plants Loads", in Modern Methods Of Construction Design, L. Ševĉik, P. Lepšík, M. Petrů, I. Mašín and R. Martonka, Eds. Cham: Springer International Publishing, 2014, pp. 273-280.

[5] DYREKTYWA RADY 1999/32/WE z dnia 26 kwietnia 1999 r. odnoszqca się do redukcji zawartości siarki $w$ 
niektórych paliwach ciekłych oraz zmieniajqca dyrektywę 93/12/EWG, Rada Unii Europejskiej, 1999.

[6] ZALECENIE KOMISJI z dnia 8 maja 2006 r. w sprawie wspierania pobierania energii elektrycznej z lqdu przez statki zacumowane w portach Wspólnoty 2006/339/ WE, Komisję Wspólnot Europejskich, 2006.

[7] DYREKTYWA RADY 2003/96/WE z dnia 27 października 2003 r. w sprawie restrukturyzacji wspólnotowych przepisów ramowych dotyczq̨cych opodatkowania produktów energetycznych i energii elektrycznej, Rada Unii Europejskiej, 2003.

[8] IEC/ISO/IEEE 80005-1 Utility connections in port - Part 1: High Voltage Shore Connection (HVSC) Systems General requirements, edition 1.0, International Electrotechnical Commission/ International Organization for Standardization/IEEE, 2012.

\section{dr inż. Dariusz Tarnapowicz}

Maritime University of Szczecin, ZEiEO

ul. Wały Chrobrego 1-2, 70-500 Szczecin, POLAND

e-mail: d.tarnapowicz@am.szczecin.pl

prof. Sergiej German-Galkin

University ITMO

Sablinskaja 14, 197101 Sankt Petersburg, RUSSIA

e-mail: ggsg@yandex.ru
[9] D. Tarnapowicz, "Synchronization of national grid network with the electricity ships network in the "shore to ship « system", Management Systems in Production Engineering, vol. 11, no. 3, pp. 9-13, 2013.

[10] IEC/ISO/IEEE 80005-3 Utility connections in port - Part 3: Low Voltage Shore Connection (LVSC) Systems General requirements, edition 1.0, International Electrotechnical Commission/ International Organization for Standardization/IEEE,2014.

[11] Port of Bergen Website. (2017, Feb. 01). Low Voltage Shore Connection - Ship side [Online]. Available: http://bergenhavn.no/onshore-power-supply-ops/ 